\title{
Invited review: Technical solutions for analysis of milk constituents and abnormal milk
}

\author{
M. Brandt, A. Haeussermann, ${ }^{1}$ and E. Hartung \\ Christian-Albrechts-University Kiel, Institute of Agricultural Engineering, 24098 Kiel, Germany
}

\begin{abstract}
Information about constituents of milk and visual alterations can be used for management support in improving mastitis detection, monitoring fertility and reproduction, and adapting individual diets. Numerous sensors that gather this information are either currently available or in development. Nevertheless, there is still a need to adapt these sensors to special requirements of on-farm utilization such as robustness, calibration and maintenance, costs, operating cycle duration, and high sensitivity and specificity. This paper provides an overview of available sensors, ongoing research, and areas of application for analysis of milk constituents. Currently, the recognition of abnormal milk and the control of udder health is achieved mainly by recording electrical conductivity and changes in milk color. Further indicators of inflammation were recently investigated either to satisfy the high specificity necessary for automatic separation of milk or to create reliable alarm lists. Likewise, milk composition, especially fat:protein ratio, milk urea nitrogen content, and concentration of ketone bodies, provides suitable information about energy and protein supply, roughage fraction in the diet, and metabolic imbalances in dairy cows. In this regard, future prospects are to use frequent on-farm measurements of milk constituents for short-term automatic nutritional management. Finally, measuring progesterone concentration in milk helps farmers detect ovulation, pregnancy, and infertility. Monitoring systems for on-farm or on-line analysis of milk composition are mostly based on infrared spectroscopy, optical methods, biosensors, or sensor arrays. Their calibration and maintenance requirements have to be checked thoroughly before they can be regularly implemented on dairy farms.
\end{abstract}

Key words: milk analysis, health monitoring, on-farm sensors, mastitis

\section{INTRODUCTION}

The current trend in dairy production can be characterized by reduced numbers of dairy farms on the

Received July 14, 2009.

Accepted October 19, 2009.

${ }^{1}$ Corresponding author: ahaeussermann@ilv.uni-kiel.de one hand and by increased herd size and lactational yield per cow on the other (Hamann, 2005). This development results in a situation in which the milker or herd manager spends less time in contact with the cow and where automatic monitoring of cows increases in importance. Automated milking systems require a suitable monitoring system to provide the farmer with a suitable decision support system (Ordolff, 2001a). Several responses of cows to their environment, such as cow activity, moving behavior, and physiological changes, are used to monitor their health and fertility. In addition, several recent research projects focused on indicators in milk to support feeding management, estrus detection, and detection of udder infections and abnormal milk (e.g., Mottram et al., 2002; Rasmussen, 2004; Hamann, 2005; Chagunda et al., 2006; Simersky et al., 2007; Hettinga et al., 2008). Alterations in milk constituents and visual appearance of milk provide valuable information on the health and reproduction status of the cow. Several sensor techniques have been developed in recent years that continuously measure such indicators on-farm during or after the milking process. They are operated either manually, such as portable on-farm milk analyzers (e.g., Ordolff, 2005; Svennersten-Sjaunja et al., 2005), or on-line (that is, in or at the milking line; e.g., Tsenkova et al., 2000; Mottram and Velasco-Garcia, 2004). However, this information is rarely used in up-to-date dairy farms. Most of these techniques are still on research level and scarcely realized on practical dairy farms. Equally important, a positive cost:benefit ratio of commercially available techniques implies that the frequent or daily information about variations of major milk constituents provides a considerable support to farm management and an additional benefit compared with monthly records. Infertility of cows and udder infections, particularly, cause high economic losses for the farms, ranking first and second, respectively, of most frequent reasons for cow replacement (Hamann and Fehlings, 2002).

This paper compiles the most important indicators in milk for milk quality control, feeding management, and reproduction monitoring in dairy farms. In addition, recently investigated sensor techniques for continuous on-farm or on-line analysis of milk are described. 


\section{APPLICATION AREAS FOR INDICATORS IN MILK}

\section{Milk Quality in the Context of Udder Infections and Abnormal Milk}

Milk quality can be related to hygienic, compositional, or consumer-relevant aspects (Hamann, 2005). It can be adversely affected during processing itself, by hygiene conditions during milking, by milking routines and technology, and by health status of the mammary gland. This paper focuses on mastitis-induced compositional deterioration in milk quality. Such deterioration is relevant because of its influence on the process properties and shelf life duration of milk (Auldist, 2002; Hamann, 2005). In this context, SCC is widely used by dairy companies as a payment parameter.

Definition and Symptoms of Mastitis. Mastitis is the inflammation of the mammary gland caused by pathogenous microorganisms, mainly bacteria and seldom fungi, yeasts, or algae. Because of the immune reaction, leukocytes enter into the mammary gland, resulting in a noticeable increase in SCC in the milk. The SCC in milk from uninfected quarters is typically $<100,000$ cells/mL (Hamann and Fehlings, 2002), whereas in infected quarters it might be up to several million cells per milliliter (Dodd and Booth, 2000).

Depending on its severity and symptoms, mastitis can be classified into acute or chronic and into clinical or subclinical (Kelly, 2002; Hamann, 2005). Visible alteration in milk, such as flakes or clots, is found especially with acute clinical forms of mastitis, characterized additionally by typical symptoms such as pain, redness, and swelling of the udder. Subclinical mastitis causes no visual alterations in the milk or udder; however, alterations in milk constituents and an elevated SCC can be observed. The term chronic mastitis refers to an udder infection that manifests for a long period of time, often accompanied by periodic clinical symptoms. Kelly (2002) estimated that 15 to 40 subclinical cases can be found for every clinical case. Detection of clinical mastitis is important for high milk quality, antibiotic treatment of the cow, and animal welfare (Kamphuis et al., 2008a). In addition, early detection of subclinical mastitis infections using suitable indicators in milk might not only help to ensure high milk quality and high milk yield but also help to prevent the infection from converting into clinical or chronic forms.

Mastitis-Induced Alterations in Milk Composition. According to Auldist (2002), the most severe alterations in milk because of subclinical mastitis, next to high SCC, are elevated quantities of free fatty acids; a reduction in casein and concomitant increase in whey protein; a reduction in lactose concentration; changes in the concentration of minerals such as sodium, chloride, potassium, and calcium; and an increase in milk $\mathrm{pH}$.
They can be found in clinical, subclinical, or chronic forms of mastitis in different intensities. Effects of subclinical mastitis on the concentration of milk constituents are compiled in Table 1.

The changes in milk constituents are caused by chemical mediators of inflammation (e.g., histamine, cytokines), bacterial toxins, and the activity of enzymes in milk (Auldist, 2002). Hydrolytic enzymes, such as $\mathrm{N}$-acetyl- $\beta$-D-glucosaminidase (NAGase) and L-lactate dehydrogenase (LDH), and proteolytic enzymes are released as a result of the animal's immune response against infection and changes in cellular membrane chemistry. Although the detection of clinical mastitis predominantly depends on visual alterations in milk, the changes in milk constituents can help to diagnose subclinical mastitis in an early stage.

Nevertheless, alterations in milk occur not only in response to subclinical mastitis. Influences of day of lactation, milking interval, milk sampling fraction, and age of the cow have to be considered for detailed interpretation. Several minerals (e.g., sodium, potassium, and chloride) as well as lactose, lactate, NAGase, and LDH are particularly powerful mastitis indicators (Kitchen et al., 1984; Mottram et al., 2002; Halm, 2003; Bruckmaier et al., 2004). A change in their concentration in milk is obviously a response to an inflammation of the udder and is to a limited extent caused by other effects (Table 1). In contrast, changes in milk fat and total protein content in milk are induced by several more influences, including feed composition. Their reaction to mastitis is very unspecific (Table 1). Other indicators, such as free fatty acids, milk $\mathrm{pH}$, and electrical conductivity (EC), respond in a specific way but are strongly influenced by technical aspects such as milk transport, air turbulences, sensor configuration, and temperature (Auldist, 2002; Rasmussen et al., 2006). Early detection of mastitis might be supported also by the correlation between different indicators, such as SCC and protein. For example, Park et al. (2007) observed a positive relationship between SCC and milk protein in healthy cows but a negative correlation in the presence of a bacterial infection.

Abnormal Milk. Separation of abnormal milk is regulated in the European Union by EC 853/2004 (European Commission, 2004), which requires that sensing methods in milking systems without a milker achieve similar results in detecting organoleptic or physicochemical abnormalities in milk as a milker in a milking parlor. As a result, the definition and the development of detection methods for abnormal milk focused mainly on organoleptic skills of milkers, particularly visual alterations in respect to its color and homogeneity. Origins of abnormal milk are either teat tissue damages (blood-stained milk) or clinical inflammations of the 
Table 1. Effects of subclinical mastitis and of increasing lactation stage, lactation number, milking interval, and sampling time during milking on milk composition

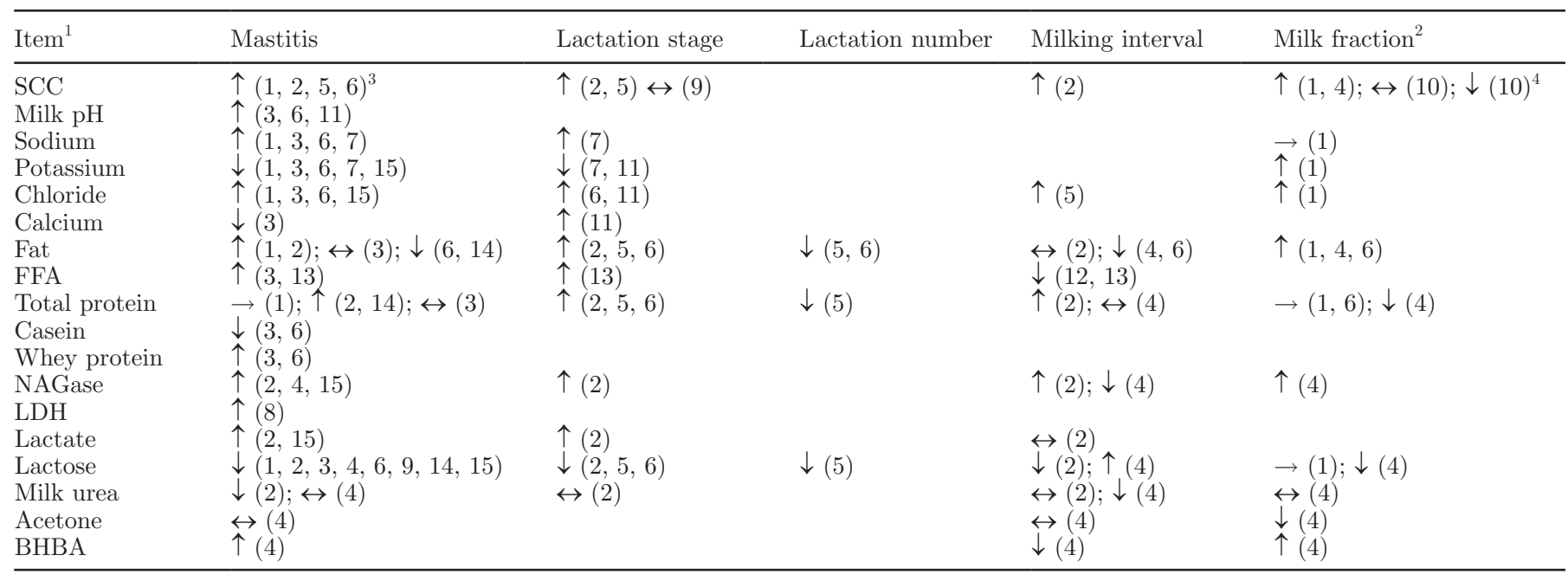

${ }^{1} \mathrm{FFA}=$ free fatty acids; NAGase $=\mathrm{N}$-acetyl- $\beta$-D-glucosaminidase LDH $=$ L-lactate dehydrogenase.

${ }^{2}$ Milk fraction $=$ sampling time during milking.

${ }^{3}$ Numbers in parentheses indicate the reference(s) corresponding to the effect ( $\uparrow$ : increase, $\downarrow$ : decrease, $\leftrightarrow$ : no change, $\rightarrow$ slight increase). References: 1) Bruckmaier et al., 2004; 2) Halm, 2003; 3) Auldist, 2002; 4) Nielsen et al., 2005a; 5) Fahr, 2003; 6) Sienkiewicz and Kirst, 2006; 7) Krehl and Brunsch, 2005; 8) Chagunda et al., 2006; 9) Ordolff, 2006; 10) Sarikaya and Bruckmaier, 2006; 11) Töpel, 2004; 12) Rasmussen et al., 2006; 13) Thomson et al., 2005; 14) Park et al., 2007; 15) Hamann, 2005.

${ }^{4}$ Dropped if basic SCC was high.

udder (mainly flakes and clots, and potentially blood). A blood stain of $0.1 \%$ blood mixed with milk can be reliably detected by consumers, professionals, or sensors (Rasmussen, 2004). Nonetheless, the differentiation between flakes and other pollutants in milk is still a challenging task if it is to be done by sensors. Rasmussen (2004) points out that, for the automatic separation of abnormal milk, the sensitivity and specificity of the sensing system should be higher than 80 and $99 \%$, respectively. A reliable reference method to detect clots in foremilk is to score its homogeneity on a filter with a pore size of $0.1 \mathrm{~mm}$ (Rasmussen, 2004). In addition, alterations in milk indicators as described above might be used for detecting abnormal milk.

\section{Feeding}

The feedback of milk composition might be directly used for nutrition monitoring and concomitant adaptation of feeding. Mottram et al. (2002) list fat, protein, urea, and acetone as most useful milk constituents with regard to metabolic and nutritional status of the cow, which are easily monitored at the same time.

Fat and protein in milk are directly connected with the energy and crude fiber supply of the dairy cow. An energy deficit reduces the rate at which bacterial protein is synthesized, resulting in a reduction of milk protein concentration; the roughage intake in relation to concentrates is reflected in the milk fat content (Kirchgessner, 1997). Because of variations in stage of lactation and milk yield, the ratio of fat to protein is in general a more sensitive indicator of metabolic status than fat or protein used separately. A fat:protein ratio between 1.2 and 1.4 is optimal and implies a positive energy balance. A higher value equals a higher risk of developing ketosis, whereas a fat:protein ratio lower than 1.1 might have its origin in rumen acidosis (Čejna and Chládek, 2005).

Another powerful indicator in relation to feeding control is the content of milk urea. An uneven nitrogen balance on the farm, caused by excessive levels of CP in the diet, can be expressed in a high urea concentration in bulk milk. The latter can be used for feed adaptation and for environmental control. According to van Duinkerken et al. (2005), a reduction in urea concentration from 40 to $20 \mathrm{mg} / 100 \mathrm{~g}$ of milk corresponds with a reduction in $\mathrm{NH}_{3}$ emission by about $44 \%$. Hence, excessive levels of $\mathrm{CP}$ do not only represent a considerable expense for the farmer, but also a significant pollutant to air and water (Kirchgessner et al., 1986; Jenkins and Delwiche, 2002). With regard to individual cows, the concurrent monitoring of MUN and milk protein can be used to detect energy malnutrition, or protein malnutrition, or both (Kirchgessner, 1997). However, diurnal variations, particularly time of sampling versus time of feeding, can affect urea concentration in milk samples 
considerably. The normal variation of urea in milk is between 3 and $6.5 \mathrm{mM}$, with a pronounced milk urea peak 2 to $4 \mathrm{~h}$ after feeding (Gustafsson, 1993).

Ketosis is a metabolic disorder apparent primarily 2 to $7 \mathrm{wk}$ postpartum as a result of an energy deficit of the cow and mobilization of body reserves. Main indicators in milk are the ketone bodies acetone, acetoacetate, and BHBA (Nielsen et al., 2005b). Mottram et al. (2002) focused on milk acetone as the most abundant ketone body present in milk, being highly correlated to blood ketone levels. Nielsen et al. (2005a) found that disturbing variables such as quarter health, milking interval, and sampling time during milking had a more pronounced effect on BHBA than on acetone concentration in milk, which makes it more important to insist on a fixed sampling procedure (Table 1).

\section{Reproduction}

The main tasks in relation to reproductive management are improved detection of ovulation and ovarian cysts and early diagnosis of pregnancy, reflected to a high extend in the progesterone cycle. The concentration of progesterone both in plasma and milk varies according to the estrus cycle of the cow. Progesterone secretion is very low on the day of estrus $(<5 \mathrm{ng} / \mathrm{mL}$ of milk), increases rapidly from d 4 to 9 of the cycle (10-40 ng/mL of milk), and remains stable until approximately $3 \mathrm{~d}$ before the next estrus on $\mathrm{d} 21$. High progesterone concentrations between d 7 and 18 after ovulation indicate an active corpus luteum. In case of pregnancy but also in the case that the estrus cycle is disrupted because of an ovarian cyst, milk progesterone concentration will remain at a high level during the period around $\mathrm{d} 21$. The interpretation of milk progesterone concentration is most promising if the information is connected to other data such as activity, milk temperature, and biographic history of the cow (Friggens and Chagunda, 2005; Pache, 2007; Simersky et al., 2007).

\section{TRENDS IN SENSOR DEVELOPMENT}

Sensors for on-farm analysis of milk composition are developed either for replacing visual inspection of foremilk by the milker (color and image sensors) or for monitoring indicators in milk that have a high informational value but are not recognizable directly by the milker. Main areas of application of the latter are feed adaptation, reproduction management, and early detection of udder infections. Measurement of EC and the California Mastitis Test (CMT) are the most common methods for mastitis detection in up-to-date milking systems. In addition, techniques for counting somatic cells and automated CMT were recently developed. Rapid and nondestructive analysis of multiple components can be realized by ultrasonic or electromagnetic waves. Key sensing techniques for enzymatic changes in milk are biosensors, whereas chemical sensors are used for detecting several mostly volatile metabolites of pathogens. The relationship between milk constituents, areas of application, and sensing techniques is presented in Figure 1.

\section{Color and Image Sensors}

Detection of abnormal color can be realized by spectroscopic but also by colorimetric measurements. It is well known that colostrum can be identified by color variations in the blue region (Ordolff, 2003) and that milk with a reddish color indicates a specific ratio of blood, which originates, for example, from udder infections or teat injuries (Ordolff, 2001b). Espada and Vijverberg (2002) tested a light-emitting diode-sensor combination consisting of the 3 light sources red, green, and blue with the task of identifying and separating abnormal milk and colostrum on-line during the milking process. Cows with clinical mastitis showed significant changes in the patterns of all 3 colors in comparison with previous milkings or with healthy quarters (Espada and Vijverberg, 2002). The system is available in automatic milking systems and was tested by Trilk et al. (2006). The authors indicated that visually modified foremilk was detected with a sensitivity of $68 \%$ but with a high percentage $(78 \%)$ of false alarms.

The visual appearance of abnormal milk can be altered furthermore by flakes and clots. A digital camera and a trained algorithm for image analysis allow the classification of particles as flakes, clots, or nonmilk particles. According to Maasen-Francke et al. (2004), such a trained algorithm potentially enables the system to identify $90 \%$ of the particles correctly as clots and other particles such as straw, sawdust, grains of sand, or foam, as well as white spots caused by reflection. The investigation indicates that image analysis might be a useful future tool for supporting the automatic detection of particles in milk. Nonetheless, it is not yet adopted in up-to-date milking systems.

\section{Cell Counters and Automated CMT}

Somatic cells are quantified in laboratories most commonly by using flow cytometers. The cell nuclei are stained (e.g., with ethidium bromide) and the cells are counted by light scatter, or fluorescent detectors, or both, as they pass in a thin film under a high-energy 


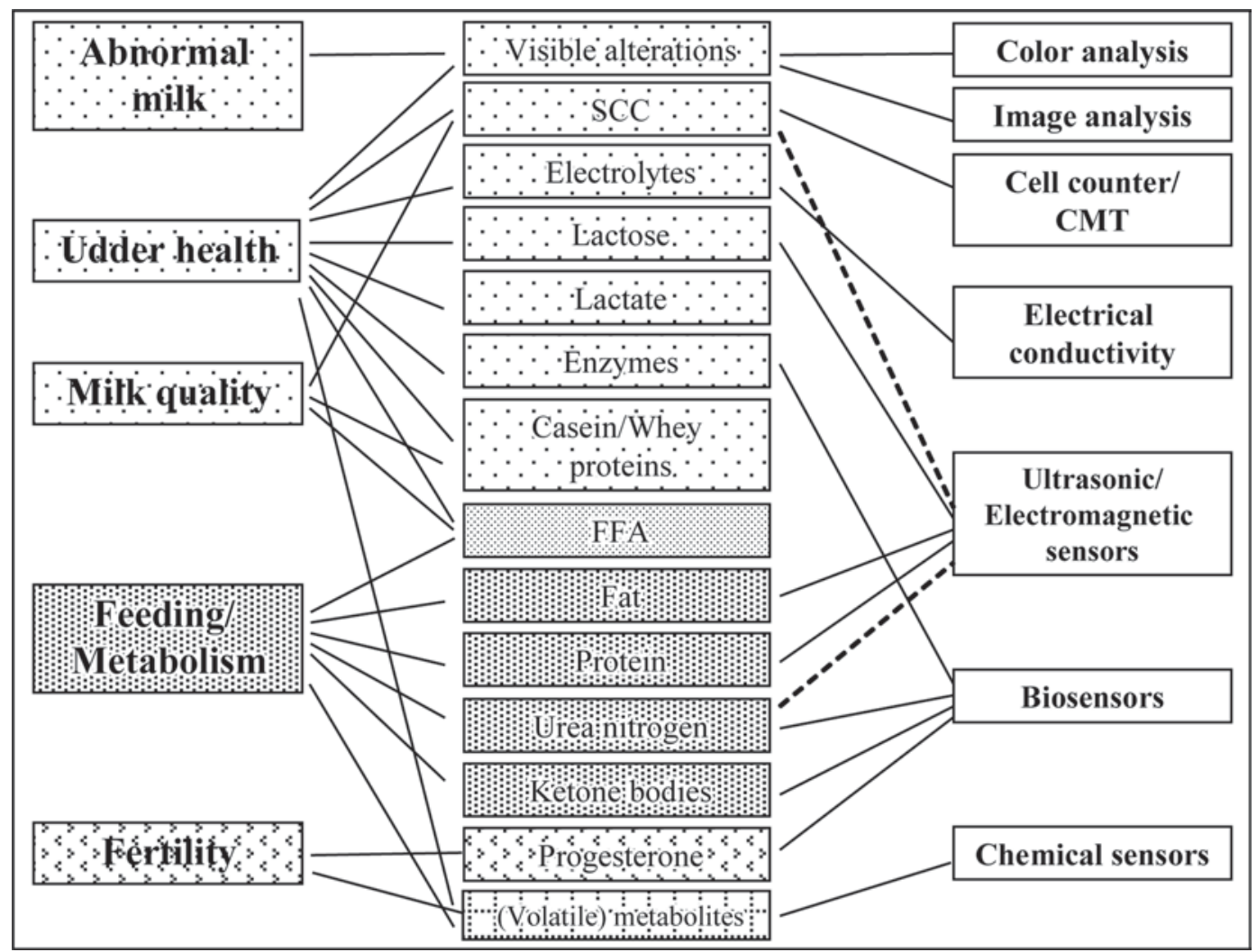

Figure 1. Indicators in milk, their application areas, and key sensing techniques. CMT = California Mastitis Test; FFA = free fatty acids.

light source. Calibrated against microscopic counts, flow cytometers can provide accurate, rapid, and precise measurement (Kelly, 2002).

In recent years, several on-farm tests for the prediction of SCC have been created. They use, for example, enzymatic color reactions (PortaSCC, PortaScience, Portland, OR) or automatic counting of stained cell nuclei based on fluorescence images (Direct Cell Counter, DeLaval, Tumba, Sweden; C-Reader, Digital Bio Technology Co., Seoul, South Korea). Comparative tests of the latter affirm in general a good agreement with the results of laboratory instruments, resulting in an $\mathrm{r}^{2}$ value of up to 0.99 (Direct Cell Counter) and 0.96 (C-Reader) in combination with high repeatability (Gonzalo et al., 2006; Sarikaya and Bruckmaier, 2006; Moon et al., 2007).

Alternatively, on-farm SCC can be determined based on CMT, developed by Schalm and Noorlander (1957) (CellSense, Sensortec Ltd., Hamilton, New Zealand) or based on a modified Wisconsin mastitis test, developed by Thompson and Postle (1964) (Somaticell, Madasa, Sao Paulo, Brazil) (Kamphuis et al., 2008b; Rodrigues et al., 2009). Whyte et al. (2004) described an automated on-line CMT that promises to enable a reasonable classification into bands of $<200,200$ to 500,500 to
$1,500,1,500$ to 5,000 , and $>5,000 \times 10^{3}$ cells $/ \mathrm{mL}$. The system was tested by Kamphuis et al. (2008b). Naturally, the correlation of the automated on-line CMT with laboratory instruments $(\mathrm{r}=0.76)$ was lower than those described above and improved little for SCC $>200$ $\times 10^{3}$ cells $/ \mathrm{mL}$. Nevertheless, Kamphuis et al. (2008b) underline that the success rate for automatic detection of clinical mastitis can be improved remarkably while reducing false alerts by combining the information of the automated on-line CMT with the information of EC using a fuzzy logic algorithm. On-line cell counters, such as the Direct Cell Counter and the automated on-line CMT, are commercially available in some automatic milking systems. Both systems use chemical reagents and are operated in a bypass line, where a milk sample is analyzed during the milking process.

\section{Electrical Conductivity}

To date, EC is the most commonly used indicator for on-line monitoring of udder health. Electrodes are inexpensive and can easily be implemented on-line. The changes in the ion concentration in mastitic milk cause an increase in EC above its normal value of approximately $4.6 \mathrm{mS} / \mathrm{cm}$ (Hogeveen and Ouweltjes, 
2002). Nevertheless, a high variation of sensitivity and specificity of 28 to $90 \%$ and 92 to $97 \%$, respectively, can be found in literature if $\mathrm{EC}$ is used for the detection of udder infections (Wiedemann, 2004). One reason for a low correlation between SCC and EC is that the latter is affected not only by mastitis infection but also by tissue inflammation. Another reason for a low sensitivity, or specificity, or both, is the strong influence of, for example, milk fraction, milk viscosity, temperature, and technical conditions on the measured result, which underlines the necessity of a clear measurement procedure and sensor calibration (Hogeveen and Ouweltjes, 2002; Bruckmaier et al., 2004). The variation of EC during milking, for example, might give additional information about quarter health status compared with absolute or relative EC readings (Barth et al., 2000). In general, EC should be measured in foremilk, or be computed together with other sensor signals, or both. The combination of EC with information about milk production rate, milk flow rate or, for example, color patterns in the green and blue region, as well as the between-quarters deviation of EC and its variation over several days, increases sensitivity and specificity for detecting udder infections, particularly if the signals are computed by eligible models such as fuzzy logic or neural networks (Wiedemann and Wendl, 2004; Cavero et al., 2006, 2007; Trilk et al., 2006; Kamphuis et al., 2008a,b; Hassan et al., 2009).

\section{Ultrasonic and Electromagnetic Sensors}

Milk constituents can be monitored rapidly and in a nondestructive manner by interactions with ultrasonic (Ordolff, 2005) or electromagnetic waves, including either visible spectra (400-700 nm), near-infrared spectra (700-2,500 nm), mid-infrared spectra $(2,500-30,000$ nm; Tsenkova et al., 2000, 2001a,b; Sjaunja, 2005), or radio frequency (kHz-GHz; Bürger and Nacke, 2005).

Ordolff (2005) tested an ultrasonic device to measure fat, protein, and lactose and concluded that the method adequately fulfils the requirements for herd management. Bürger and Nacke (2005) investigated dielectric properties of milk in the frequency range between 10 $\mathrm{kHz}$ and $10 \mathrm{MHz}$. Impedance, capacity, conductance, and phase shift were strongly influenced by SCC and particularly by lactose concentration in milk.

The method commonly used to analyze fat, protein, and lactose in laboratories is based on mid-infrared (MIR) spectroscopy. According to Svennersten-Sjaunja et al. (2005), MIR spectroscopy features a high accuracy and repeatability, both when milk is analyzed in the laboratory and when it is analyzed with a portable on-farm device (FMA2001, Miris AB, Uppsala, Sweden). Because of the limited penetration depth that makes the spectra very sensitive to the presence of fat globules or fat biofilms, MIR spectroscopy is not suitable for on-line raw milk analysis (Linker and Etzion, 2009). Homogenization can improve measurement accuracy, but it is not practicable for on-line analysis. According to Soyeurt et al. (2006), MIR spectroscopy can be a suitable instrument for determining fatty acid concentration and profiles in cow milk. The method could predict most fatty acids in a faster and less expensive way than routine laboratory methods and has the potential for use in regular milk recording.

The main advantage of near-infrared (NIR) spectroscopy in comparison to MIR is that the sensor is cheaper, although less accurate. Because NIR spectroscopy requires little or no sample preparation, it is particularly suitable for on-line use and provides real-time information in a process stream (Schmilovitch et al., 2000; Tsenkova et al., 2000; Woo et al., 2002; Ordolff, 2005; Woodcock et al., 2008). Schmilovitch et al. (2000) tested the suitability of NIR measurements of nonhomogenized, fresh raw cow milk. The authors achieved promising results measuring fat distribution in flowing raw milk and other heterogeneous fluids. Accurate results are obtained by developing individual calibration models per cow (Tsenkova et al., 2000), although periodic updating of the calibration sample set and the model are required (Kawasaki et al., 2008). Suitable wavelength regions are 1,100 to $2,500 \mathrm{~nm}$ (Tsenkova et al., 2001a), but also 600 to 1,050 nm (Kawasaki et al., 2008). The authors analyzed fat, protein, and lactose, SCC, and MUN content. Woo et al. (2002) determined fat, lactose, and protein in a spectral range of 700 to $1,100 \mathrm{~nm}$. The study resulted in low standard errors of prediction of $0.06,0.10$, and $0.10 \%$ for fat, lactose, and protein, respectively. Tsenkova et al. (2006) developed a spectroscopic model that enabled the prediction SCC as well as mastitis-causing pathogens. According to Tsenkova et al. (2001b), an elevated SCC changes the spectra of milk because of alterations in milk proteins as well as changes in the concentration of electrolytes. Effects of a high SCC on the accuracy of the determination of fat, protein, and lactose in a wavelength region of 700 to $1,100 \mathrm{~nm}$ should be accounted for either in the calibration model or by initial classification of the milk samples according to their SCC (Tsenkova et al., 2001b). Schmilovitch et al. (2007) and Katz et al. (2007) described a commercial NIR analyzer (IMA, AfiMilk, S.A.E Afikim, Israel) that uses the wavelength region between 450 and $950 \mathrm{~nm}$ and measures milk solid concentrations as well as the presence of blood and the level of somatic cells in milk on-line in a milking parlor.

Spectroscopic measurements in the visible spectrum can be used to detect color changes in milk. Investiga- 
tions of Wiedemann and Wendl (2004) resulted in a suitable evaluation of milk quality in the wavelength band between 400 and $520 \mathrm{~nm}$. Spectral reflection was advantageous compared with colorimetric measurements because it disregards the strong influence of fat content on milk color. The combination of EC and spectral photometry enabled Wiedemann and Wendl (2004) to correctly classify $85 \%$ of healthy quarters with less than 100,000 cells $/ \mathrm{mL}$ and $71 \%$ of infected quarters with more than 500,000 cells/mL (specificity of $95 \%)$.

\section{Biosensors}

Enzymatic reactions, as described by Pemberton et al. (2001a), Jenkins and Delwiche (2002), and Mottram et al. (2002), are another powerful tool for measuring milk constituents. Biosensors consist of a biological component (e.g., an enzyme, antibody, or microorganism) directly connected to a transducer such as an electrode, a piezoelectric, or an optical sensor. Their potential application in relation to feeding, milk quality, or reproduction is monitoring MUN, acetone, NAGase, $\mathrm{LDH}$, lactose, and progesterone.

Eshkenazi et al. (2000) developed a biosensor to determine lactose concentration in raw milk down to concentrations of a few micromoles. The sensor was based on a 3-enzyme cascade sensor and could be used as an on-line lactose sensor in a milking parlor. A manometric biosensor for measurement of milk urea was developed by Jenkins and Delwiche (2002). The assay involved the enzymatic hydrolysis of urea and subsequent measurement of $\mathrm{CO}_{2}$ partial pressure. The simple and inexpensive sensor allowed the measurement of milk urea inside a range of 2 to $7 \mathrm{mM}$ with a standard error of approximately $0.25 \mathrm{mM}$ and is capable of being used on-line in a milking system. The most severe challenges for on-line utilization are measurement duration and technical requirements for accurate manometric recordings.

An electrochemical sensor to detect concentrations of NAGase in buffer solution, based on amperometric detection of l-naphtol at a screen-printed carbon electrode, was reported by Pemberton et al. (2001a). A similar principle, operated in a competitive immunoassay, was applied by Pemberton et al. (2001b) to determine progesterone concentration in milk. Calibration plots were obtained over the range 0 to $25 \mathrm{ng} / \mathrm{mL}$ and the assay was particularly optimized to discriminate between milk progesterone concentrations of $0,2.5$, and $5 \mathrm{ng} / \mathrm{mL}$. The system was tested in an 8-stall milking parlor where the sampling lines were linked from each milking point to a central buffer system, resulting in a good agreement $\left(\mathrm{r}^{2}>0.9\right)$ with data from a commercial enzyme immunoassay (Mottram and Velasco-Garcia, 2004).

Claycomb and Delwiche (1998) developed an on-line biosensor, based on a rapid enzyme immunoassay and spectral detection, calibrated for progesterone concentrations of 0.1 and $5 \mathrm{ng} / \mathrm{mL}$. Reusability of the test in multiple test cycles was limited by residual enzyme. Enzyme immunoassays in combination with colorimetric or spectral sensors are used for half- or fully automated, portable on-farm milk progesterone tests. Nevertheless, their use in estrus detection is often limited by the strict requirement to accurately detect and discriminate low progesterone concentrations.

\section{Chemical Sensors}

Gas sensor arrays, so-called electronic noses, are applied for detecting volatile substances in agricultural production and process control. Chemical changes during contact of an analyte with a sensitive surface layer are transformed by signal transduction (Casalinuovo et al., 2006). Modern sensor arrays consist of several sensor types (highly selective, partially selective, or crosssensitive) and electrochemical, gravimetric, or optical transduction principles (Rudnitskaya and Legin, 2008). Pattern recognition methods are used for processing characteristic smells or volatile compounds produced by microorganisms during growth. Electronic tongues apply a similar principle to liquid components with a high capability for more accurate quantification (Rudnitskaya and Legin, 2008).

An application area for chemical sensors in animal husbandry is the detection of diseases during which characteristic volatile metabolites are produced. Applications in the area of milk composition, feeding, and reproduction in dairy cows are diagnosis of ketosis by measuring acetone in milk or expired air (Elliott-Martin et al., 1997), tracing of odor changes associated with cows' estrus (Lane and Wathes, 1998), and detection of milk from cows with acute clinical mastitis. The latter was tested in a few experimental designs, using metal oxide semiconductive field effect transistor (MOSFET) gas sensor array technology in combination with a $\mathrm{CO}_{2}$ sensor (Eriksson et al., 2005), dynamic headspace GCMS (gas chromatography-mass spectrometry) for identification of volatile metabolites up to specific mastitis pathogens (Eriksson et al., 2005; Hettinga et al., 2008), or an electronic tongue (Mottram et al., 2007). To measure the gas concentration of milk, time for heating (up to $25 \mathrm{~min}$; Eriksson et al., 2005) or incubation (up to $14 \mathrm{~h}$; Hettinga et al., 2008) of the milk sample and, depending on the system, a recovery time of the sensor array are required, which limits the on-line use of chemical sensors. 


\section{DISCUSSION}

The increasing automation process in milking technology has in recent years resulted in the development of numerous technical solutions for analysis of milk constituents. Several milk constituents can provide the herd manager with valuable information about the health, feeding, and reproduction status of dairy cows (Table 1). The selection of the most relevant indicators in milk and related sensing techniques depends on the field of application-reproduction, feeding, or detection of udder infections and abnormal milk - on the one hand and the possibility to easily adapt sensors to on-farm requirements on the other hand. In general, sensitivity and specificity of applied sensors have to be the main factors in an evaluation, beside calibration and maintenance requirements, operating cycle duration, costs, and robustness. Sensitivity and specificity are important to ensure longevity on-farm, to provide reliable alarm lists, and to be applicable for process automation (Hogeveen and Ouweltjes, 2002; Mottram et al., 2002).

One of the obstacles in widespread use of sensors or specific indicators is the complexity of effects on milk constituents and the individuality of cows' reactions to several influences (Hogeveen and Ouweltjes, 2002; Nielsen et al., 2005a). Most inventive research projects therefore result either in techniques that enable the detection of more than one milk constituent, such as infrared spectroscopy (Tsenkova et al., 2001a,b, 2006) or biosensors (Pemberton et al. 2001a,b; Mottram et al., 2002; Figure 1), or they linked risk factors and biographic history with several characteristic model input variables (Friggens and Chagunda, 2005; Chagunda et al., 2006; Friggens et al., 2007). These can be milk constituents but also related factors such as milk yield, milk flow rate, milk temperature, and milk color, or activity of cows and physiological data. Chagunda et al. (2006) and Friggens et al. (2007) described a biological model for detecting mastitis $4 \mathrm{~d}$ before treatment. The real-time information of LDH in milk was combined with known biological risk factors of mastitis, such as days since calving, breed, parity, milk yield and EC. Commercially (herd navigator; Herd Navigator Danmark A/S, Foss Analytical A/S, Hillerød, Denmark; DeLaval International AB, Tumba, Sweden), measurements of progesterone, urea, and BHBA are included as well in order to monitor not only udder health but also reproduction and metabolic status (Mills, 2008). To reduce operation time and costs, the system automatically selects cows of which a sample should be taken.

The benefit of sensing systems depends in general on their reasonable application and their possibility to reduce cow replacement, expenses for feeding, and mastitis-related costs. Adequately low investment and operating costs are crucial, as is a thorough concept for integrating the sampling system and sensors in a concise way in the milking system (e.g., in a bypass or buffer system if the system is supposed to be operated in a milking parlor; Mottram and Velasco-Garcia, 2004). Otherwise, the additional operating costs or additional workload might restrict use.

\section{CONCLUSIONS}

It is well known that alterations in milk constituents can be used for health monitoring in dairy cows. Characteristic indicators in milk of udder health, feeding, and reproduction are somatic cells, minerals, lactose, and hydrolytic enzymes; fat:protein ratio, milk urea, and ketone bodies; and progesterone, respectively.

In recent years, sensor development increasingly focused on on-farm utilization and consisted of color sensors, cell counters, NIR sensors, ultrasonic sensors, and biosensors. Measurement of electrical conductivity was partly methodically enhanced. Image analysis, gas sensor arrays, and headspace gas chromatography-mass spectrometry are upcoming technologies in respect to milk quality and detection of udder inflammation.

Technology that enable the detection of more than one milk constituent, such as infrared spectroscopy, biosensors, or chemical sensors, is presumed to show the most potential for comprehensive use in more than one application field. In addition, risk factors and biographic history are linked to the sensor information.

\section{REFERENCES}

Auldist, M. 2002. Effect on processing characteristics. Pages 20022006 in Encyclopedia of Dairy Science. H. Roginski, J. W. Fuquay, and P. F. Fox, ed. Academic Press Inc., London, UK.

Barth, K., R. Fischer, and H. Worstorff. 2000. Evaluation of variation in conductivity during milking to detect subclinical mastitis in cows milked by robotic systems. Pages 89-96 in Proc. Int. Symp. on Robotic Milking. H. Hogeveen and A. Meijering, ed. Wageningen Pers, Wageningen, the Netherlands.

Bruckmaier, R. M., C. E. Ontsouka, and J. W. Blum. 2004. Fractionized milk composition in dairy cows with subclinical mastitis. Vet. Med. - Czech 49:283-290.

Bürger, C., and T. Nacke. 2005. Zellzahlbestimmung in der Rohmilch. Landtechnik 60:160-161.

Casalinuovo, I. A., D. Di Pierro, M. Coletta, and P. Di Francesco. 2006. Application of electronic noses for disease diagnosis and food spoilage detection. Sensors 6:1428-1439.

Cavero, D., K.-H. Tölle, C. Buxadé, and J. Krieter. 2006. Mastitis detection in dairy cows by application of fuzzy logic. Livest. Sci. 105:207-213.

Cavero, D., K.-H. Tölle, G. Rave, C. Buxadé, and J. Krieter. 2007. Analysing serial data for mastitis detection by means of local regression. Livest. Sci. 110:101-110.

Čejna, V., and G. Chládek. 2005. The importance of monitoring changes in milk fat to protein ratio in Holstein cows during lactation. J. Central Eur. Agric. 6:539-545.

Chagunda, M. G. G., N. C. Friggens, M. D. Rasmussen, and T. Larsen. 2006. A model for detection of individual cow mastitis based on an indicator measured in milk. J. Dairy Sci. 89:2980-2998. 
Claycomb, R. W., and M. J. Delwiche. 1998. Biosensor for on-line measurement of bovine progesterone during milking. Biosens. Bioelectron. 13:1173-1180.

Dodd, F. H., and J. M. Booth. 2000. Mastitis and milk production. Pages 213-255 in The Health of Dairy Cattle. A. H. Andrews, ed. Blackwell Science, Hoboken, NJ.

European Commission. 2004. EC 853/2004 of the European parliament and of the council of 29 April 2004 laying down specific hygiene rules for food of animal origin. European Union, Brussels, Belgium.

Elliott-Martin, R. J., T. T. Mottram, J. W. Gardner, P. J. Hobbs, and P. N. Bartlett. 1997. Preliminary investigation of breath sampling as a monitor of health in dairy cattle. J. Agric. Eng. Res. 67:267275 .

Eriksson, Á., K. Persson Waller, K. Svennersten-Sjaunja, J. -E. Haugen, F. Lundby, and O. Lind. 2005. Detection of mastitic milk using a gas-sensor array system (electronic nose). Int. Dairy J. 15:1193-120.

Eshkenazi, I., E. Maltz, B. Zion, and J. Rishpon. 2000. A threecascaded-enzymes biosensor to determine lactose concentration in raw milk. J. Dairy Sci. 83:1939-1945.

Espada, E., and H. Vijverberg. 2002. Milk colour analysis as a tool for the detection of abnormal milk. Pages IV29-IV38 in Proceedings of the First North American Conference on Robotic Milking, Wageningen, the Netherlands. Wageningen Academic Press, Wageningen, the Netherlands.

Fahr, R.-D. 2003. Tier- und umweltbedingte Einflussfaktoren auf die milchleisstung, milchinhaltsstoffe und qualitätsmerkmale. Pages 102-124 in Milcherzeugung. R. D. Fahr and G. V. Lengerken, ed. Deutscher Fachverlag GmbH. Frankfurt am Main, Germany.

Friggens, N. C., and M. G. G. Chagunda. 2005. Prediction of the reproductive status of cattle on the basis of milk progesterone measures: Model description. Theriogenology 64:155-190.

Friggens, N. C., M. G. G. Chagunda, M. Bjerring, C. Ridder, S. Hoisgaard, and T. Larsen. 2007. Estimating degree of mastitis from time-series measurements in milk: A test of a model based on lactate dehydrogenase measurements. J. Dairy Sci. 90:54155427.

Gonzalo, C., B. Lingage, J. A. Carriedo, F. de la Fuente, and F. San Primitivo. 2006. Evaluation of the overall accuracy of the DeLaval cell counter for somatic cell counts in ovine milk. J. Dairy Sci. 89:4613-4619.

Gustafsson, A. H. 1993. Acetone and Urea Concentration in Milk as Indicators of the Nutritional Status and the Composition of the Diet of Dairy Cows. PhD Diss. Swedish University of Agricultural Sciences, Uppsala.

Halm, H. 2003. Zum Einfluss eines Automatischen Melkverfahrens auf Milchmengenleistung und Milchinhaltsstoffe Hochleistender DH-Kühe unter Berücksichtigung von Laktationsstadium und Eutergesundheit. PhD Thesis. School for Veterinary Medicine, Hannover, Germany.

Hamann, J. 2005. Diagnosis of mastitis and indicators of milk quality. Pages 82-91 in Mastitis in Dairy Production: Current Knowledge and Future Solutions. H. Hogeveen, ed. Wageningen Academic Publishers, Wageningen, the Netherlands.

Hamann, J., and K. Fehlings. 2002. Leitlinien zur Bekämpfung der Mastitis des Rindes als Bestandsproblem. 4th ed. Verlag der Deutschen Veterinärmedizinische Gesellschaft E.V. (DVG), Gießen, Germany.

Hassan, K. J., S. Samarasinghe, and M. G. Lopez-Benavides. 2009. Use of neural networks to detect minor and major pathogens that cause bovine mastitis. J. Dairy Sci. 92:1493-1499.

Hettinga, K. A., H. J. F. van Valenberg, T. J. G. M. Lam, and A. C. M. van Hooijdonk. 2008. Detection of mastitis pathogens by analysis of volatile bacterial metabolites. J. Dairy Sci. 91:3834-3839.

Hogeveen, H., and W. Ouweltjes. 2002. Automatic on-line detection of abnormal milk. Pages 1735-1740 in Encyclopedia of Dairy Science. H. Roginski, J. W. Fuquay, and P. F. Fox, ed. Academic Press Inc., London, UK.

Jenkins, D. M., and M. J. Delwiche. 2002. Manometric biosensor for on-line measurement of milk urea. Biosens. Bioelectron. 17:557563.
Kamphuis, C., D. Pietersma, R. van der Tol, M. Wiedemann, and H. Hogeveen. 2008a. Using sensor data patterns from an automatic milking system to develop predictive variables for classifying clinical mastitis and abnormal milk. Comput. Electron. Agric. 62:169-181.

Kamphuis, C., R. Sherlock, J. Jago, G. Mein, and H. Hogeveen. 2008b. Automatic detection of clinical mastitis is improved by in-line monitoring of somatic cell count. J. Dairy Sci. 91:4560-4570.

Katz, G., A. Arazi, N. Pinsky, I. Halachmi, Z. Schmilovitch, E. Aizinbud, and E. Maltz. 2007. Current and near term technologies for automated recording of animal data for precision dairy farming. J. Anim. Sci. 85(Suppl. 1):377.

Kawasaki, M., S. Kawamura, M. Tsukahara, S. Morita, M. Komiya, and M. Natsuga. 2008. Near-infrared spectroscopic sensing system for on-line milk quality assessment in a milking robot. Comput. Electron. Agric. 62:22-27.

Kelly, A. L. 2002. Test methods and standards. Pages 1995-2001 in Encyclopedia of Dairy Science. H. Roginski, J. W. Fuquay, and P. F. Fox, ed. Academic Press Inc., London, UK.

Kirchgessner, M. 1997. Tierernährung. 10th ed. DLG-Verlags-GmbH, Frankfurt, Germany.

Kirchgessner, M., M. Kreuzer, and D. A. Roth-Maier. 1986. Milk urea and protein content to diagnose energy and protein malnutrition of dairy cows. Arch. Anim. Nutr. 36:192-197.

Kitchen, B. J., G. Middleton, W. S. Kwee, and R. J. Andrews. 1984 N-acetyl-beta-D-glucosaminidase (NAGase) levels in bulk herd milk. J. Dairy Res. 48:167-188.

Krehl, I., and R. Brunsch. 2005. Evaluation of ions sodium and potassium in milk as a criteria of change of blood-milk-barrier-A lactation study. Pages 149-155 in Precision Livestock Farming '05. S. Cox, ed. Wageningen Academic Publishers, Wageningen, the Netherlands.

Lane, A. J. P., and D. C. Wathes. 1998. An electronic nose to detect changes in perineal odors associated with estrus in the cow. J. Dairy Sci. 81:2145-2150.

Linker, R., and Y. Etzion. 2009. Potential and limitation of midinfrared attenuated total reflectance spectroscopy for real time analysis of raw milk in milking lines. J. Dairy Res. 76:42-48.

Maasen-Francke, B., M. Wiethoff, O. Suhr, C. Clemens, and A. Knoll. 2004. A method to detect flakes and clots in milk in automatic milking systems. Page 251 in Automatic Milking-A Better Understanding. A. Meijering, H. Hogeveen, and C. J. A. M. de Koning, ed. Wageningen Academic Publishers, Wageningen, the Netherlands.

Mills, R. 2008. On farm analysis. An eye on the future. Foss in Focus $32: 18-20$

Moon, J. S., H. C. Koo, Y. S. Joo, S. H. Jeon, D. S. Hur, C. I. Chung, H. S. Jo, and Y. H. Park. 2007. Application of a new portable microscopic somatic cell counter with disposable plastic chip for milk analysis. J. Dairy Sci. 90:2253-2259.

Mottram, T., A. Rudnitskaya, A. Legin, J. L. Fitzpatrick, and P. D. Eckersall. 2007. Evaluation of a novel chemical sensor system to detect clinical mastitis in bovine milk. Biosens. Bioelectron. 22:2689-2693.

Mottram, T., M. Velasco-Garcia, P. Berry, P. Richards, J. Ghesquiere, and L. Masson. 2002. Automatic on-line analysis of milk constituents (urea, ketones, enzymes and hormones) using biosensors. Comp. Clin. Pathol. 11:50-58.

Mottram, T., and M. N. Velasco-Garcia. 2004. Development and testing of on-line biosensors for automated fertility management of dairy cows. Page 14 in 3rd International Workshop on Smart Sensors in Livestock Monitoring, September 10-11, 2004. (CD) Laboratory for Agricultural Buildings Research, K. U. Leuven, Leuven, Belgium.

Nielsen, N. I., N. C. Friggens, M. G. G. Chagunda, and K. L. Ingvartsen. 2005b. Predicting risk of ketosis in dairy cows using in-line measurements of $\beta$-hydroxybutyrate: A biological model. J. Dairy Sci. 88:2441-2453.

Nielsen, N. I., T. Larsen, M. Bjerring, and K. L. Ingvartsen. 2005a. Quarter health, milking interval, and sampling time during 
milking affect the concentration of milk constituents. J. Dairy Sci. $88: 3186-3200$.

Ordolff, D. 2001a. Introduction of electronics into milking technology. Comput. Electron. Agric. 30:125-149.

Ordolff, D. 2001b. Einsatz von Farbmessung zur Bewertung von Vorgemelken. Bau, Technik und Umwelt in der Landwirtschaftlichen Nutztierhaltung, Hohenheim, Germany, March 6-7, 2001. KTBL, Darmstadt, Germany.

Ordolff, D. 2003. Veränderung der Milchbeschaffenheit zu Laktationsbeginn. Bau, Technik und Umwelt in der Landwirtschaftlichen Nutztierhaltung, Vechta, Germany. KTBL, Darmstadt, Germany.

Ordolff, D. 2005. Untersuchungen zur bewertung der milchqualität durch mobile systeme zur milchanalyse. Bericht des Instituts für Betriebstechnik und Bauforschung. Page 134 in Jahresbericht 2005. Bundesforschungsanstalt für Landwirtschaft (FAL), Braunschweig, Germany.

Ordolff, D. 2006. Aussagekraft von standard-milchinhaltsstoffen zur bewertung der eutergesundheit. Landtechnik 61:48-49.

Pache, S. 2007. Elektronikeinsatz zur gesundheits und fruchtbarkeitsüberwachung. Pages 101-113 in Precision Dairy Farming. KTBL-Schrift 457, KTBL, Darmstadt, Germany.

Park, Y. K., H. C. Koo, S. H. Kim, S. Y. Hwang, W. K. Jung, J. M. Kim, S. Shin, R. T. Kim, and Y. H. Park. 2007. The analysis of milk components and pathogenic bacteria isolated from bovine raw milk in Korea. J. Dairy Sci. 90:5405-5414.

Pemberton, R. M., J. P. Hart, and T. T. Mottram. 2001a. An assay for the enzyme N-acetyl- $\beta$-D-glucosaminidase (NAGase) based on electrochemical detection using screen-printed carbon electrodes (SPCEs). Analyst (Lond.) 126:1866-1871.

Pemberton, R. M., J. P. Hart, and T. T. Mottram. 2001b. An electrochemical immunosensor for milk progesterone using a continuous flow system. Biosens. Bioelectron. 16:715-723.

Rasmussen, M. D. 2004. Detection and separation of abnormal milk in automatic milking systems. Pages 189-197 in Automatic Milking-A Better Understanding. A. Meijering, H. Hogeveen, and C. J. A. M. de Koning, ed. Wageningen Academic Publishers, Wageningen, the Netherlands.

Rasmussen, M. D., L. Wiking, M. Bjerring, and H. C. Larsen. 2006. Influence of air intake on the concentration of free fatty acids and vacuum fluctuations during automatic milking. J. Dairy Sci. 89:4596-4605.

Rodrigues, A. C. O., L. D. Cassoli, P. F. Machado, and P. L. Ruegg. 2009. Short communication: Evaluation of an on-farm test to estimate somatic cell count. J. Dairy Sci. 92:990-995.

Rudnitskaya, A., and A. Legin. 2008. Sensor systems, electronic tongues and electronic noses, for the monitoring of biotechnical process. J. Ind. Microbiol. Biotechnol. 35:443-451.

Sarikaya, H., and R. M. Bruckmaier. 2006. Importance of the sampled milk fraction for the prediction of total quarter somatic cell count. J. Dairy Sci. 89:4246-4250.

Schalm, O. W., and D. O. Noorlander. 1957. Experiments and observations leading to the development of the California mastitis test. J. Am. Vet. Med. Assoc. 130:199-204.

Schmilovitch, Z., G. Katz, E. Maltz, M. Kutscher, M. Sarig, I. Halachmi, A. Hoffman, , H. Egozi, and E. Unar. 2007. Spectroscopic fluid analyzer. US Patent no. 7236237.

Schmilovitch, Z., I. Shmulevich, A. Notea, and E. Maltz. 2000. Near infrared spectrometry of milk in its heterogeneous state. Comput. Electron. Agric. 29:195-207.

Sienkiewicz, T., and E. Kirst. 2006. Analytik von Milch und Milcherzeugnissen. Behr's Verlag, Hamburg, Germany.

Simersky, R., J. Swaczynova, D. A. Morris, M. Franek, and M. Strnad. 2007. Development of an ELISA-based kit for the onfarm determination of progesterone in milk. Vet. Med. (Praha) $52: 19-28$.

Sjaunja, L.-O. 2005. A review of spectroscopic methods and their suitability as analytical techniques for farm testing. Pages 25-32 in Precision Livestock Farming '05. S. Cox, ed. Wageningen Academic Publishers, Wageningen, the Netherlands.
Soyeurt, H., P. Dardenne, F. Dehareng, G. Lognay, D. Veselko, M. Marlier, C. Bertozzi, P. Mayeres, and N. Gengler. 2006. Estimating fatty acid content in cow milk using mid-infrared spectrometry. J. Dairy Sci. 89:3690-3695.

Svennersten-Sjaunja, K., M. Sjögren, I. Andersson, and L.-O. Sjaunja. 2005. Milk analyses: A comparison between simple IR-instrument for use on farm level and available IR-methods. Pages 141-147 in Precision Livestock Farming '05. S. Cox, ed. Wageningen Academic Publishers, Wageningen, the Netherlands.

Thompson, D. I., and D. S. Postle. 1964. The Wisconsin mastitis test-An indirect estimation of leukocytes in milk. J. Milk Food Technol. 27:271-275.

Thomson, N. A., M. W. Woolford, P. J. A. Copeman, and M. J. Auldist. 2005. Milk harvesting and cow factors influencing seasonal variation in the levels of free fatty acids in milk from Waikato dairy herds. N.Z. J. Agric. Res. 48:11-21.

Töpel, A. 2004. Chemie und Physik der Milch. 1st ed. B. Behr's Verlag GmbH \& Co. KG, Hamburg, Germany.

Trilk, J., K. Münch, and C. Franke. 2006. Untersuchungen zur feststellung von eutergesundheitsstörungen und Rohmilchveränderungen mit dem MQC und weiteren technischen einrichtungen beim automatischen melksystem Lely Astronaut. Pages 80-89 in Schriftenreihe des Landesamtes für Verbraucherschutz, Landwirtschaft und Flurneuordnung, Reihe Landwirtschaft, Band 7 Heft V. MLUV, Brandenburg, Germany.

Tsenkova, R., S. Atanassova, K. Itoh, Y. Ozaki, and K. Toyoda. 2000. Near infrared spectroscopy for biomonitoring: Cow milk composition measurement in a spectral region from 1,100 to 2,400 nanometers. J. Anim. Sci. 78:515-522.

Tsenkova, R., S. Atanassova, S. Kawano, and K. Toyoda. 2001a. Somatic cell count determination in cow's milk by near-infrared spectroscopy: A new diagnostic tool. J. Anim. Sci. 79:25502557.

Tsenkova, R., S. Atanassova, H. Morita, K. Ikuta, K. Toyoda, I. K. Iordanova, and E. Hakogi. 2006. Near infrared spectra of cow's milk for milk quality evaluation: Disease diagnosis and pathogen identification. J. Near Infrared Spectroscopy 14:363-370.

Tsenkova, R., S. Atanassova, Y. Ozaki, K. Toyoda, and K. Itoh. 2001b. Near-infrared spectroscopy for biomonitoring: Influence of somatic cell count on cow's milk composition analysis. Int. Dairy J. $11: 779-783$

van Duinkerken, G., G. André, M. C. J. Smith, G. J. Monteny, and L. B. J. Sebek. 2005. Effect of rumen-degradable protein balance and forage type on bulk milk urea concentration and emission of ammonia from dairy cow houses. J. Dairy Sci. 88:1099-1112.

Whyte, D. S., R. G. Orchard, P. Cross, T. Frietsch, R. W. Claycomb, and G. A. Mein. 2004. An on-line somatic cell count sensor. Pages 235-240 in Automatic Milking - A Better Understanding. A Meijering, H. Hogeveen, and C. J. A. M. de Koning, ed. Wageningen Academic Publishers, Wageningen, the Netherlands.

Wiedemann, M. 2004. Überwachung der Eutergesundheit bei Milchkühen durch Kombination Verschiedener ChemischPhysikalischer Messwerte. PhD Thesis. Technische Universität München, Germany.

Wiedemann, M., and F. Wendl. 2004. The use of spectral photometry for detection of mastitis milk. Pages 229-233 in Automatic Milking - A Better Understanding. A. Meijering, H. Hogeveen, and C. J. A. M. de Koning, ed. Wageningen Academic Publishers, Wageningen, the Netherlands.

Woo, Y. A., Y. Terazawa, J. Y. Chen, C. Iyo, F. Terada, and S. Kawano 2002. Development of a new measurement unit (MilkSpec-1) for rapid determination of fat, lactose, and protein in raw milk using near infrared transmittance spectroscopy. Appl. Spectrosc. 56:599-604.

Woodcock, T., G. Downey, and C. P. O'Donell. 2008. Better quality food and beverages: The role of near infrared spectroscopy. J Near Infrared Spectroscopy 16:1-29. 